\title{
日蒸発・蒸散量の簡便な分離推定手法の検討
}

\section{A Simple Method for Separately Estimating Daily Evaporation and Transpiration}

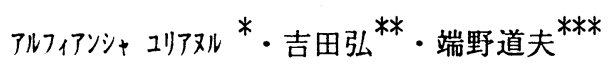

By Alfiansyah YULIANUR, Hiromu YOSHIDA and Michio HASHINO

Evapotranspiration is one of the most impotant components of hydrological circulation for water resources planning and management. Simple method requiring a few meteorological data which are easily obtained is necessary for analysis on water balance in large-scale area, especially in developing countries. Furthermore, evaporation caused by rainfall interception, and transpiration should be divided, because they are different hydrological processes in themselves. In this study, a simple mathematical models for separately estimating daily transpiration and evaporation in rainfall events were developed. The models were applied to the observation obtained in a small forested mountain basin in Tokushima prefecture, and the validity of the models were investigated.

Keywords : transpiration, evaporation, forested basin, mathematical model division of evapotranspiration

\section{1.はじめに}

蒸発散量は水資源開発・管理計画の策定上で重要な水文循環要素である．近年，たとえば地球規模での水 循環過程に大きな役割を果たしていることが明らかになってきた熱帯雨林地方などは概して水文気象観測網 の不十分な発展途上国に位置することが多く，当然のことながらきわめて限られた情報しか入手できない状 態にある．また広域での蒸発散量を推定する必要があることで, 地上情報に頼る限りは面的な情報を入手す ることは不可能に近い，さらには，蒸発量と蒸散量は異なる水文素過程により生起することから，本来的に はきちんと分離して評価されるべきものであるが，現状ではこれらを分離評価しうる実用的な手法は提案さ れていない，著者らはこうした現状認識の下で，GMSテータを利用した広域水収支評価手法の開発を目指 し， I Rデータと雲量データを利用した日降雨量推定モテルの開発に取り組んできた ${ }^{1)}$. 本論文では, 山地 小流域での流出解析で蓄積されてきた知見を基礎に, 広域的な蒸発量, 蒸散量推定手法の開発に向けた足が かりとして，簡便な日遮断蒸発量および日蒸散量の推定モテルの開発を試みた．特に日遮断蒸発量について は先に開発されたGMS - I R および雲量テータを利用した日降雨量推定モテルによる推定日降雨量の利用 を念頭においた．開発したモテルを山地小流域で観測されたテータにそれぞれ適用し，現地観測テータの再 現性によりそれぞれのモテルの妥当性について検証することで, 将来の広域水収支解析に関する可能性につ いて検討を加えた.

\begin{tabular}{|c|c|c|c|c|c|c|}
\hline * & 学生員 & & 徳島大学大学院 & 工学研究科開発保全工学専攻 & （訳70 & 徳島市南常三島町2-1) \\
\hline$* *$ & 正会員 & 工博 & 徳島大学助手 & 工学部建設工学科 & ( & 上 \\
\hline$* * *$ & 7 I & 工博 & 徳島大学教授 & 工学部建設工学科 & ( & 上 \\
\hline
\end{tabular}




\section{2. モテルの概要}

\section{1 遮断蒸発モテル}

遮断蒸発モテルは，まずGMS 赤外輝度温度デーとと雲量データを利用して日降雨量を推定するGMS 日 降雨量推定モテル" と日降雨量から日遮断蒸発量を推定する線形回㷌日遮断量推定モテル2”とからなる.

(a) GMS 日降雨量推定モテル

WE F A X画像テータとして配信される赤 外輝度温度 (I R) テータの解像度 ( 1 画素) は, $0.05^{\circ} \times 0.05^{\circ}($ 約 $5 \mathrm{~km} \times 5 \mathrm{~km})$ であり, 雲頂 温度に対応する輝度温度 $\left(0 \mathrm{~K}^{\circ} \sim 402 \mathrm{~K}^{\circ}\right)$ が0 〜15の16階調の整数值として 1 時間ごとに受 信可能である．本解析では図-1に示すよう に，I Rテータは $0.25^{\circ} \times 0.25^{\circ}$ スケールのグ リッドについて日平均値として整理される.

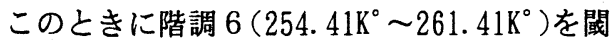
值として，これよりもI Rテータの大きな画 素の含有率をクールスポット率 F c と定義

し，降雨の集中度を表現する指標之位置づけ ている. 本モテルでは従来のモテルとは異な り, I RやF c などの指標を単独の説明変数 とするだけでなく，これらを組み合わせたす のも説明変数として採用している点が特徵で

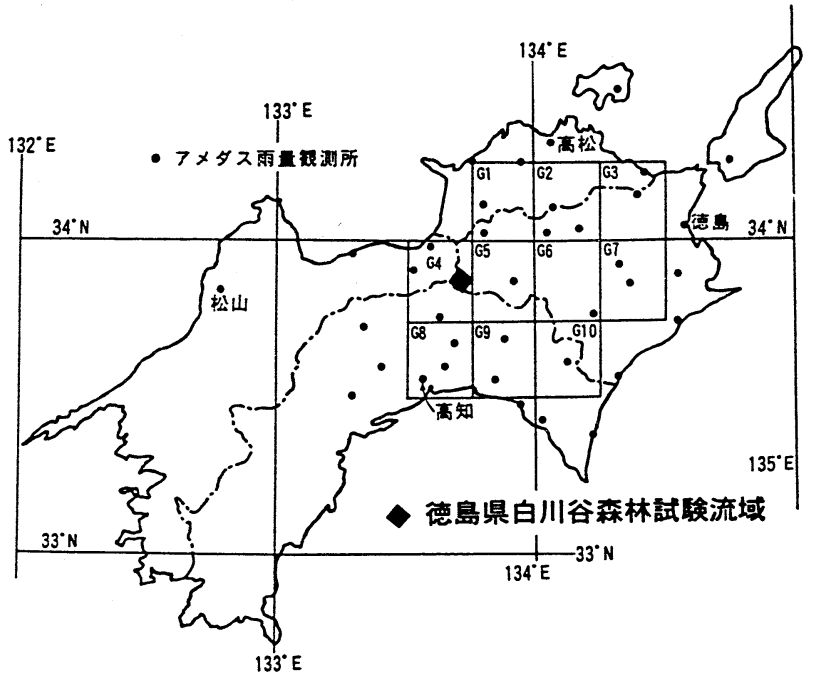

図-1 GMS テータの解析対象地域

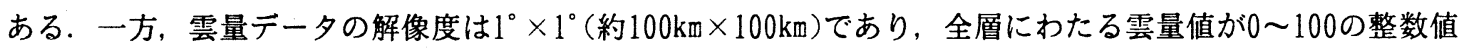
で表現されている. 雲量データには $400 \mathrm{hPa}$ 相当する高度を境として, それより上の上層雲量UC，それよ り下の下層雲量 L C ，およびこれらを合わせた全層雲量 T C の 3 種類があり，1ヶ月ごとに配布される.こ れは雲量が即時処理される 1 次テータではなくGPVテータ等を利用して作成される 2 次テータであるため である. 雲量テータについては上層雲量 U C と下層雲量 L C との差を C L と定義する. I R, F c , C L , U C ， L C およびT C の各指標を適宜組み合わせることで複数の説明変数を考案し，様々な組み合わせにつ いて検討する. なお日降雨量Rに関する重回帰式を作成する上で, 先に考案した説明変数の 3 次の項までを 式中で考慮する. 回帰係数の同定に当たっては日降雨量 Rに現地で観測された林外雨量を与え，ステップワ イズ回帰法を用いて決定係数が最も大きくなるような説明変数の組み合わせを探索し，そのときの回帰係数 を求める.

(b)線形回㷌日遮断量推定モテル

線形回帰日遮断量推定モテルは, Hor ton ${ }^{31}$ が提案した次式のモテルを基礎としている.

$$
\mathrm{I}=\mathrm{b}+\mathrm{K} \text { e } \mathrm{T}_{\mathrm{R}}
$$

ここに, $\mathrm{I}$ : 遮断蒸発量, $\mathrm{e}$ : 蒸発強度, $\mathrm{T}_{\mathrm{R}}$ : 降雨継続時間, $\mathrm{b}, \mathrm{K}:$ 係数である. 彼のモテルでは降雨 中蒸発強度 $\mathrm{e}$ は一定であり, 式中では降雨強度の影響が全く考慮されていないので, 降雨量の多い場合や降 雨強度の大きい場合には十分に遮断蒸発量を過小評価する傾向がある．こうした点を考慮して，著者らの開 発した降雨遮断タンクモテル4)の考え方を応用し，回帰係数 $\mathrm{K} に$ 降雨強度および蒸発強度の影響を加味する よう工夫したのが(2)式である. 林外雨量 $\mathrm{R}$ は定義より平均降雨強度 $\mathrm{r}$ と降雨継続時間 $\mathrm{T}$ 積で表されるか ら, Hortonの(1)式と等置して見ればモテルの第 2 項について $\mathrm{K} \mathrm{e} \sim \mathrm{a} \mathrm{E}_{\mathrm{H}} \mathrm{r}$ となっていることがわかる. つ まり降雨中蒸発強度に対して降雨強度 $\mathrm{r}$ の影響を考慮している点と, 降雨中蒸発強度を一定と固定せずに気 
温とともに変化するHamonの可能蒸発散量を基準蒸発量として採用している点が特徵である. 本モテルで遮 断蒸発量の算定に関して必要となる気象テータは日平均気温と林外雨量のみである.

$$
I=b+a E_{H} R
$$

ここで, $\mathrm{I}$ : 遮断蒸発量, $\mathrm{R}$ : 降雨量, $\mathrm{E}_{\mathrm{H}}$ : Hamonの可能蒸発散量, $\mathrm{a}, \mathrm{b}:$ 回帰係数であり, それぞれ $\mathrm{a}$ $=1.86, \mathrm{~b}=3.0$ と既に同定されている. 本モテルは本来ならば一降雨イベントが適用対象であるが, 今回 は日降雨量に対して適用し, 降雨イベント単位のみならず日単位でのモテルの適用性について検討する.

\section{2 重回帰日蒸散量推定モテル}

流域の蒸散量を推定するのは一般に大変困難であるが, 著者らは樹液流速の指標であるヒートパルス速度 を利用したヒートパルス蒸散モテル ${ }^{5)}$ を構筑しており, このモデルより蒸散量の単独推定が可能である. そこで, ヒートパルス蒸散モテルの日蒸散量推定值 $\mathrm{E}_{\text {丁d }}$ 真值とし, これとHamonの可能蒸発散量 $\mathrm{E}_{\mathrm{H}}$ との比 $\phi_{\mathrm{d}}=\mathrm{E}_{\mathrm{Td}} / \mathrm{E}_{\mathrm{H}}$ を蒸散係数 $\phi_{\mathrm{d}}$ と定義して， $\phi_{\mathrm{d}}$ の簡便推定モテルの構筑を試みる．これまでのヒートパルス 蒸散モテルによる現地観測テータの解析結果から, 月単位について蒸散量とPenmanの可能蒸発散量との比 $\phi$ が純放射量, 気温, 飽差および風速を説明変数として実用的に見て十分な精度で表現できること䚁を明らか にしてきた．こうした経験に基ついて，今解析では気温，日照時間および降雨量のみが入手可能情報とする 制約条件の下で全天日射量 $\mathrm{Q} g$ ， 日平均気温 $\mathrm{T}$ おび゙月降雨量 $\mathrm{R}_{\mathrm{m}}$ を説明変数に採用し，これらの 3 次の項 まで考虑に入れた蒸散係数 $\phi$ dに関する重回帰モテルの構築と検証を試みた. 重回帰モテルの回帰係数の決 定にはステップワイズ回帰法を用い，決定係数が最大となるような説明変数の組み合わせを選択し，その場 合の回帰係数を求めた. 本モデルで必要となる気象テー夕は, 日平均気温, 照時間, 月降雨量のみである.

\section{3. 解析対象流域の概要}

本モテルを適用した流域は図-2に示す徳島県 白川谷森林試験流域である. 徳島, 愛媛および 高知県の県境に位置するため, 図-1ではG 4 の グリッドに属する．流域面積は23ha，標高は740 $\sim 1100 \mathrm{~m}$, 流域平均勾配は21. $5^{\circ}$ である. 土培は 主として褐色森林土が分布している，植生は下 流3/5が人工スギ林（約 $23 \sim 37$ 年生），上流 $2 / 5$ が天然広葉樹林となっている. 林外雨量, 樹冠 通過雨量および樹幹流下量は約 35 年生のスギを

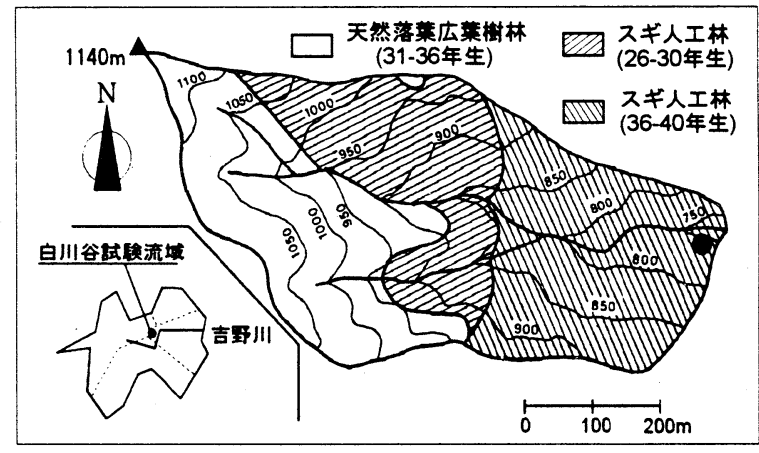

図-2 德島県白川谷森林試験流域の概要

対象として転倒マス型雨量計により10分間隔で観測されている. 少数の転倒マス型雨量計のみでは樹冠通過 雨量の空間的偏りの影響が現れる可能性が大きいことから，約 $7.2 \mathrm{~m}^{2}$ の大型集水板での観測も併用している. 遮断蒸発量は（林外雨量一樹冠通過雨量一樹幹流下量）から算定される. 気象量（気温, 相対湿度, 純放射 量, 風速) の観測機器は約22mのタワー上に設置されており,樹冠上の約 $2 m$ 地点で観測されている. ヒート パルス速度は約35年生のスギを対象に胸高付近で表皮から約 $10 \mathrm{~mm}$ 深さにセンサーを設置して観測している. 土㙋水分ポテンシャルは対象とするスギの付近で $10 \mathrm{~cm} \sim 70 \mathrm{~cm}$ 範囲で $10 \mathrm{~cm}$ こに計測されている. いずれの 観測とも図中の○地点で実施されている.

\section{4. モテルの適用と検証}

\section{1 GMS日降雨量モデルの適用結果}

本モテルを1990年と1991年の日降雨量 $5 \mathrm{~mm}$ 超えるデータへ適用して選択された説明変数は全部で15個で あったが, そのうちで日降雨量との偏相関係数が高い上位 5 つの説明変数を偏相関係数の大きい順に並へる と, $\mathrm{F} \mathrm{c}^{3}, \mathrm{~F} \mathrm{c}^{2},(1 / \mathrm{F} \mathrm{c})^{3},(\mathrm{~F} \mathrm{c} \cdot \mathrm{UC})^{2},(\mathrm{I} \mathrm{R} \cdot \mathrm{F} \mathrm{c})^{3}$ である. 上位 3 つに降雨の集中度に関係する 


\section{表-1 モデル適用時の決定係数と推定誤差の一管}

\begin{tabular}{cccc}
\hline 年 & 決定係数 & 標準誤差 $(\mathrm{mm})$ & 標準誤差率 $(\%)$ \\
\hline $1990 \& 1991$ & 0.9175 & 14.8 & 22.9 \\
1990 & 0.9595 & 14.2 & 15.0 \\
1991 & 0.6633 & 15.1 & 33.6 \\
\hline
\end{tabular}

と考えられる F c が含まれているのが注目される. 表一 1にモテル適用時の決定係数と推定誤差の一覧を示す. 表中の標準誤差とは, Root Mean Square Errorのこと であり，標準誤差を平均值で規準化することにより標 準誤差率を定義した. 1990年と1991年を通して適用し た結果では決定係数が0.9175, 標準誤差では $14.8 \mathrm{~mm}$ なった. 2 年間の平均降雨量が約 $65 \mathrm{~mm}$ であるので, 標 準誤差率は22.9\%となった.1990年のみを対象に適用 した場合には，決定係数および標準誤差ともに良好な 值が得られている。しかし1991年については，あまり 高い精度は得られていない.1990年には約 $360 \mathrm{~mm}$ の台風 性の降雨イベントがあるのに対して1991年には100mmを 超える降雨イベントが 1 つしかい。したがって説明 変数の選択と回帰係数のチューニングに1990年の豪雨 イベントが大きな影響を及ぼしている可能性がある.

モテルによる日降雨量の推定結果を図-3に示す．図一

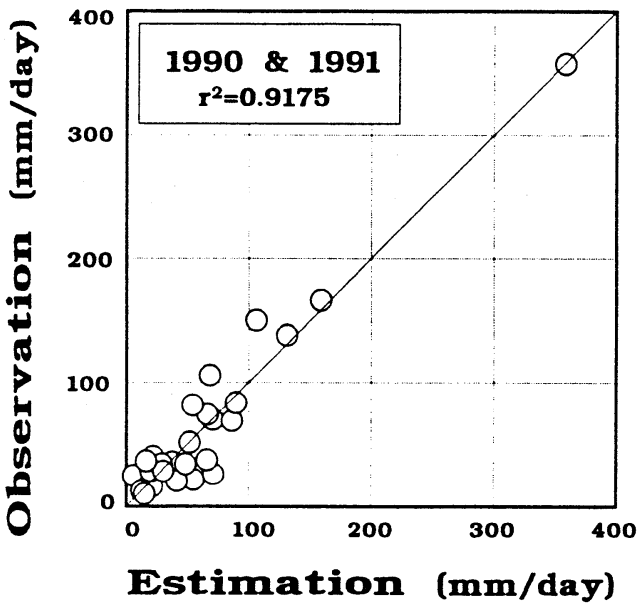

図-3 モテルによる推定日降雨量 と観測值の比較

3より，およそ50mmよりも日降雨量の大きいイベントでは過小評価，50m地りも小さなイベントでは過大評 価の傾向が認められが，全般的にみてモデル推定值と観測值は一致しているようである． $0.25^{\circ} \times 0.25^{\circ}(25$ $\mathrm{km} \times 25 \mathrm{~km})$ という広領域での GM S データの平均值と, $0.23 \mathrm{~km}^{2}$ という狭い領域での点観測雨量デタとを比 較しているため，本来的にはそう高い精度を期待するのは難しいが，今回のように約 $20 \%$ 強であれば実用的 にはまずまずの精度で推定できたと考えたい．したがって，何らかの方法で日平均気温を推定できるように なれば，気象台のルーチンデータ用いずに遮断蒸発量を推定する手法の開発に見通しが立ったと考える.

\section{表-2 モテル適用時の決定係数と推定誤差の一覧}

\begin{tabular}{cccc}
\hline 年 & 決定係数 & 標準誤差 $(\mathrm{mm})$ & 標準誤差率 $(\%)$ \\
\hline $1990 \& 1991$ & 0.9111 & 3.72 & 25.6 \\
1990 & 0.9704 & 2.85 & 14.5 \\
1991 & 0.6724 & 3.73 & 33.4 \\
\hline
\end{tabular}

\section{2 線形回舅日遮断量推定モテルの適用結果}

GMS 日降雨量推定モデルによる推定日降雨量を林外雨量Rとして与え，1990年と1991年に対して日単位 での降雨遮断蒸発量を推定した結果を示す. 表-2はモテル適用時の決定係数と推定誤差を一覧にして示した ものである. 2 年間を通しての決定係数は 0.9111 , 標準誤差は $3.72 \mathrm{mmm}$ であった. 平均遮断蒸発量が $14.5 \mathrm{~mm}$ であるので標準誤差率では $25.6 \%$ となる.日降雨量推定時の决定係数および標準誤差率とほぼ同様であるの で，日降雨量の推定精度に見合った結果である．この場合も，やはり1990年の方が1991年よりも推定精度は 高いようである．各年に単独で適用した場合も日降雨量の推定精度とほぼ同等である. 
図-4にモデルによる推定日遮断蒸発量と現地での雨 量観測テータから算定された観測值との比較結果を示 す．全般的に見てモテルによる観測值の再現性は良好 である．本来的には降雨イベントに対して適用される モテルであるが，日単位についても適用することが可 能であることが示されたと考える.

\section{3 重回帰日蒸散量推定モデルの適用結果}

重回帰蒸散量推定モテルを1991年〜1993年の 3 年間 に適用して月ごとに得られた決定係数，標準誤差なら びに標準誤差率を表-3に示す，冬季でかつ標本データ 数の少なかった1月，2月，11月および12月を除いて， 尞散活動の活発な 8 ヶ月間について決定係数は 0.85 以 上となっている．標準誤差率もこれらの 8 ヶ月では 10 \%以内に収まっている。

図-5に月ごとについてモテルによって推定された $\phi_{\mathrm{d}}$ と観測值との関係をまとめて示す．冬季の一部を除い

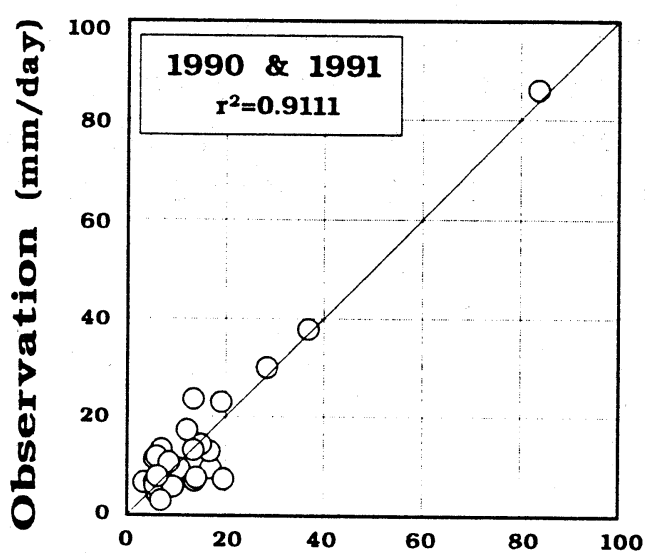

Estimation (mm/day)

図-4 モデルによる推定日遮断蒸発且と 钼測值の比較

て両者はよく一致しているのがわかる．したがって，予めヒートパルス蒸散モデルを適用しておけば，後は GMSデー夕等を用いて全天日射量あるいは日照時間を推定できれば, 気象台ルーチンデータを用いずとも 日蒸散量を実用的に十分な精度で推定しうる可能性が示されたと考える.

\section{表-3 モデの適用時の決定係数と推定誤差の一管}

\begin{tabular}{lcccccccccccc}
\hline \multicolumn{1}{c}{ 月 } & 1 & 2 & 3 & 4 & 5 & 6 & 7 & 8 & 9 & 10 & 11 & 12 \\
\hline 決定係数 & 0.50 & 0.69 & 0.96 & 0.91 & 0.86 & 0.95 & 0.88 & 0.87 & 0.93 & 0.94 & 0.52 & 0.44 \\
標準誤差 & 0.18 & 0.09 & 0.05 & 0.14 & 0.10 & 0.04 & 0.03 & 0.03 & 0.04 & 0.04 & 0.12 & 0.29 \\
標準誤差率 (\%) & 13.1 & 8.56 & 5.42 & 8.23 & 9.34 & 4.77 & 5.18 & 4.19 & 5.14 & 6.98 & 10.7 & 29.2 \\
\hline
\end{tabular}

5. おわりに

入手可能な水文気象テータが制約されているような場合でも実用的に十分な精度で遮断蒸発量と蒸散量を 分離して推定しうる手法の開発を目標に，GMS 日降雨量推定モデルおよび線形回帰日遮断量推定モデと の組み合わせで日遮断蒸発量の推定モデル構築した。また著者らのヒートパルス蒸散モテルを基礎とした 重回帰日蒸散量推定モテルを構築した。これらのモテルを徳島県白川谷森林試験流域での観測テータおよび この流域を含む地域のGMS－I Rデータと雲量データを用いて提案した手法の妥当性について検討した. その結果，GMSテータおよび比較的入手しやすい気温，降雨量と日照時間のテータがあれば簡便に遮断蒸 発量および蒸散量を日単位で分離して推定する手法の構筑に見通しが立った．特に地上の日平均気温と全天 日射量あるいは日照時間をリモートセンシングデータ等によって推定することができれば, 気象台のルーチ ンテータを必要としない日遮断蒸発量および日蒸散量の推定手法の開発も夢ではない.ただし，当然のこと ではあるがモテル定数のチューニングのために, グランドトゥルースとして解析対象流域での遮断蒸発特性 および蒸散特性を予め捉えておく必要があるのはいうまでもない．今後は地上日平均気温および全天日射量 をリモートセンシングデータから推定する手法について検討する予定である.

\section{考考文献}

1)アルフイアンシや，吉田，端野：水工学論文集, Vol. 40, pp. 291-296, 1996. 
2) 吉田, 端野, 暒田: 水文・水資源学会研究発表会要旨集, pp. 112-113，1996.

3)Horton: Monthly Weather Review, 47, pp.603-623, 1919.

4) 吉田, 端野, 村岡 : 水文·水資源学会誌, 6 (1), pp. 19-30, 1993.

5)吉田, 端野, 村岡: 水文・水資源学会誌, 6(4), pp. 350-357, 1993.

6)越智, 吉田, 端野: 年講概要集 II, pp. 792-793, 1996.
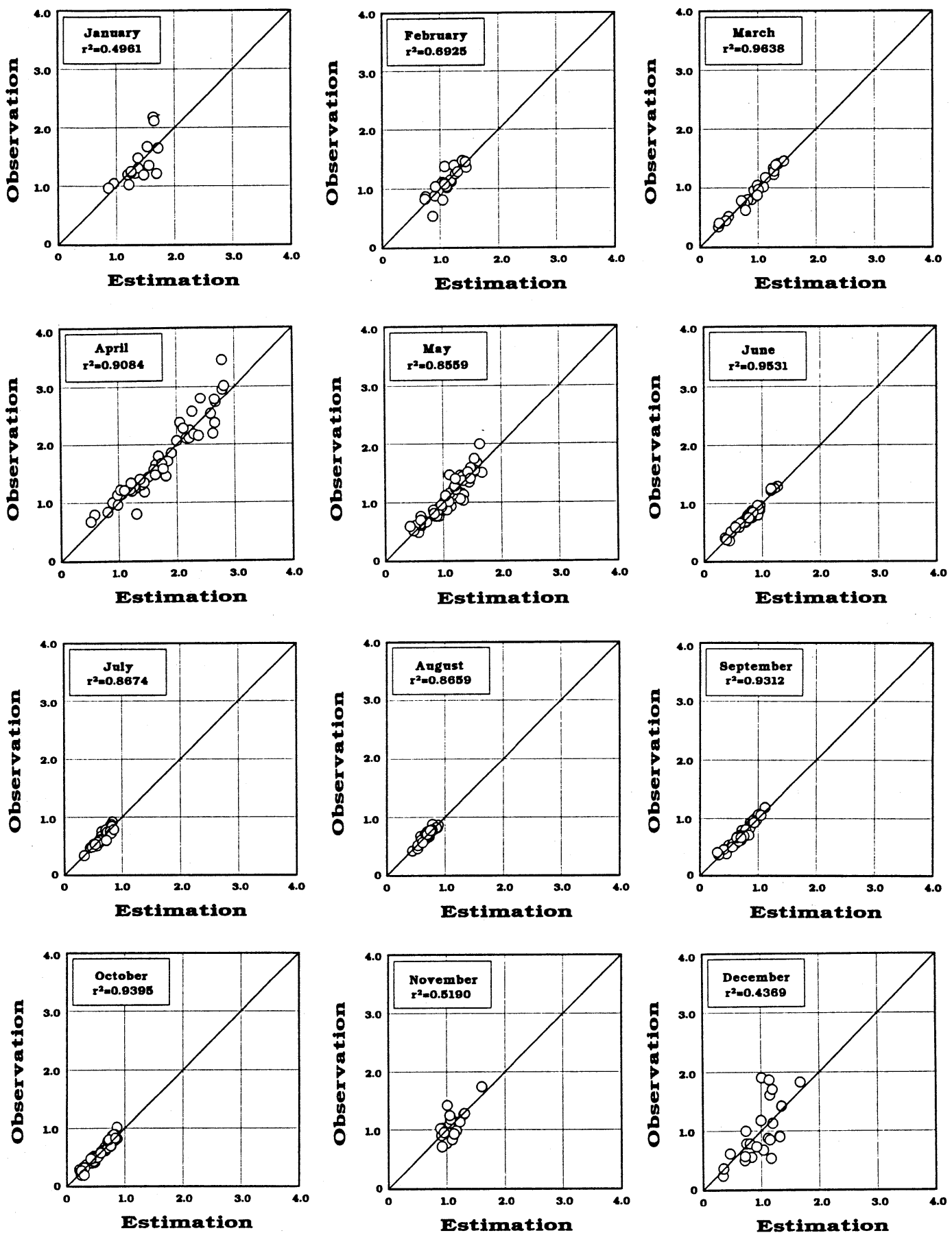

図-5 モデルによる月ことでの蒸散係数 $\phi$ 。の推定值と钼測値の比較 